JOURNAL OF INSTITUTE OF ECONOMIC DEVELOPMENT AND SOCIAL RESEARCHES

ISSN: 2630-6166

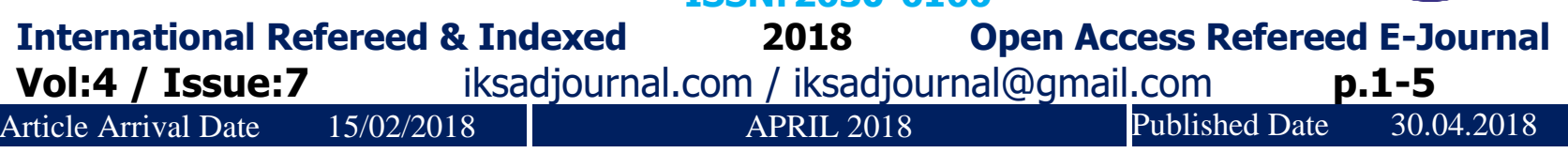

\title{
BASIC THOUGHTS IN KAZAKH APHORISMS: ON THE EXAMPLE OF WORKS BY A.SULEYMENOV AND Z.KABDULOV
}

\section{КАЗАК АФОРИЗМДЕРІНДЕГІ КУАТТЫ ОЙЛАР: А. СУЛЕЙМЕНОВ, З.КАБДОЛОВ ШЫҒАРМАЛАРЫ НЕГТЗІНДЕ}

L.M. ADILBEKOVA

Candidate of Philology, Professor, Republic of Kazakhstan

M.B. KOPESBAEVA

Master of 1 course, Republic of Kazakhstan

\begin{abstract}
The article considers the artistic power and peculiarities of the aphorisms of Kazakh poets and writers, It is a rare and original genre literature. This article is about the aphorisms - the most popular genre among poet writers, i.e. about the beauty, deepness of worr construction and power of aphorisms. XXI century is the century of technologies and digital age, but despite this century of books already vital for moral development. Also, short, understandable aphorisms, maxims that can describe the big and deep idea in two wor were always interesting for every reader. It is clear that in the era of digital technologies, developed means of communication and accessit internet, importance of thousand works of every genre: literary, cultural, scientific, classical and others printed by printing house has a $\mathrm{t}$ impact to the readers. In this article you can find a lot of theses on the means of development of aphorisms as genre in the literatu: According to the analysis, aphorism as one of the genres of Kazakh literature was not fully explored to this day. Aim of this article is give versatile information on establishment of the new genre in Kazakh literature, also advantages and specificity of aphorisms in Kaza literature was fully explored. History of catchwords is as deep and large as their scope. It is easy to prove the fact that aphorisms refle the history and vital problems of the time, when they were written. Aphorisms as genre play an important role in literature due to the fi that they are top of mind every time, despite they are ancient form of literature that didn't require relevance till our days. So we can $\mathrm{s}$ that in the time of huge data of information, role of aphorisms is increasing day by day. Nowadays philosophers, linguists, litterateurs 1 to use aphorisms in their activities during exploration of this genre. We have to admit the fact that aphorism is firstly literary genre.
\end{abstract}

Keywords:Kazakh aphorisms, Askar Suleimenov, Zeynolla Kabdulov, artistic power, independence, genre.

\section{АНДАТПА}

Мақалада қай әдебиетте болмасын ақын-жазушылардың сирек қалам тартатын жанры - қанатты сөздер, яғни афоризмдерд көркемдік ерекшеліктері, құрылымы мен ой қуаттылығы туралы қарастырылады. Адамзат баласы жиырма бірінші ғасыр аттаған және де биік технология мен цифрлы дәуірге аяқ басқанына қарамастан, кітап ғасыры адами капиталды рухал жетілдірудің бірден бірі жолы ретінде өз құнын жойған жоқ. Сонымен бірге, әдеби жанрлар ішінде шағын көлемді көрк шығармалар мен бір қазан ойды бір қасық сөзбен жеткізуге қауһарлы, айтылуы көркем әрі ырғақты болып келетін сентенциялє григерийлер, афоризмдер мен қанатты сөздер қашан да қырман сұранысына еге болып келеді. Мемлекет көлеміндегі мыңдағ баспаханалардан шығып жатқан түрлі саладағы әдеби, ғылыми, мәдени еңбектерге күніне толығып жататын ақпарат басылымдарды қоссақ, интернет пен технология заманы саналатын XXI ғасырда оқырман назары әлі де кітапта екендігіне к жеткізу киын емес. Мақалада қазақ әдебиетіндегі тақырыптық жанрлық аясы күні бүгінге дейін арнайы қарастырылмаған, сон да адамзат ақыл-ойының квинтэссенциялық көрсеткіші болып табылатын қанатты сөздер мәселесіне арналып отыр. Қанат сөздердің ауқымы қанша кең болса, тарихы да сонша терең болып келеді. Қанатты сөздер - өз дәуірі тудырған замана таңбасю арқалайтындығын, оған қатысты барлық проблемаларды көтеретіндігін, кейде тарихи оқиғаларға нақты әсер ететіндігін ғылыг дәлелдеп шығуға болады. Ой иесі, сөз иесі адам туралы жанр болып табылатын қанатты сөздер әдебиеттің бір қарағанда кө түріне жатқанымен де, интеллектуалдық өнердің теңдессіз түрі ретінде бүгінгі қоғамда нағыз ғұмырлы жанрға жатады. Бүгінгід ақпараттар ағымы айрықша ағылған заманда, афоризимдердің мәні артуда десек қателеспейміз. Кемелдігіне қатысты философт тілдік бірлік ретінде лингвистер, поэтикалық сұлу, әрі ықшам көркем сөз тіркесі ретінде әдебиетшілер афоризмдерді өз аясы: тартып, өз тұрғысынан бағалауға тырысып келген, әрі бұл үрдіс жалғасуда. Әйтсе де, афоризм, ең алдымен әдеби жанр екендіг мойындауға тиістіміз.

Түйін сөздер: Қазақ афоризмдері, Асқар Сүлейменов, Зейнолла Қабдолов, көркемдік куаты, тәуелсіздік, жанр. 
Тәуелсіз мемлекетіміздің бай, кемел де көркем әдебиетінің бар екендігіне ешкім де шек келтірмейді. Республика көлеміндегі бұрыннан және жүздеген жана ашылған баспаханалардан шығып жатқан түрлі саладағы әдеби, ғылыми, мәдени еңбектерге күніне толығып жататын ақпаратты басылымдарды қоссақ, интернет пен технология заманы саналатын XXI ғасырда оқырман назары әлі де кітапта екендігіне көз жеткізу киын емес. Осы бір ақ қағаз бетіне теріліп, сан мыңдаған тиражбен таралып жатқан ағымды жарияланымдарда тақырыбына, мазмұны мен құрылымына, яғни жанрына қарамастан кеңінен қолданылатын бір үрдіс бар. Ол қанатты сөздерді қолдану үрдісі. Сіз оны көркем әдебиеттен де, ғылыми жұмыстан да, әкімнің баяндамасынан да, басшының есебінен де, тіпті күнделікті оқитын газетіміздің бетінен де кездестіреміз.

Көп жылдар көлемінде «Ақшамның афоризмдерінде» үзбей шыққан ақын Кадыр Мырзалиевтің «Алмас жерде қалмас» [1] кітабынан алынған үзінділерді «Алматы Ақшамының кітапханасы» айдарымен қалың оқырман сүйсіне оқып отырды десек кателеспейміз. Әйтсе де, қолына қалам алғанның қолданысына еркін түсетін бұл сөздер қай жағынан болмасын, тақырыптық тұрғыдан да, жанрлық тұрғыдан да әдебиет ғылымында арнайы зерделенбеген. Сондықтан да мақала қазақ әдебиетіндегі тақырыптық жанрлық аясы күні бүгінге дейін арнайы қарастырылмаған, сонда да адамзат ақыл-ойының квинтэссенциялық көрсеткіші болып табылатын қанатты сөздер мәселесіне арналды.

Қанатты сөздердің ауқымы қанша кең болса, тарихы да сонша терең. Адамзат тарихында қанатты сөздер - өз дәуірі тудырған замана таңбасын арқалайтындығын, оған қатысты барлық проблемаларды көтеретіндігін, кейде тарихи оқиғаларға нақты әсер ететіндігін ғылыми дәлелдеп шығуға болады. Өмір туралы , оның негізгі тірегі «Ноmo sapiens» - ой иесі, сөз иесі адам туралы жанр болып табылатын қанатты сөздер әдебиеттің бір қарағанда көне түріне жатқанмен де, интеллектуалдық өнердің теңдессіз түрі ретінде бүгінгі қоғамда нағыз ғұмырлы жанрға жатады. Бүгінгідей ақпараттар ағымы айрықша ағылған заманда, қашанда «тоқсан ауыз сөздің тобықтай түйінін» бере білетін «оймақтай ой» - афоризимдердің мәні артуда десек қателеспейміз.

Ағылшын, неміс, француз, орыс әдебиеттеріне сүйенсек, қанатты сөздерге берілген нақты тұжырым әзірге жоқ. Ой тереңдігі мен кемелдігіне қатысты философтар, тілдік бірлік ретінде лингвистер, поэтикалық сұлу, әрі ықшам көркем сөз тіркесі ретінде әдебиетшілер афоризмдерді өз аясына тартып, өз тұрғысынан бағалауға тырысып келген, әрі бұл үрдіс жалғасуда. Әйтсе де, орыс филологтары тұжырымына сүйенсек, афоризм, ең алдымен әдеби жанр екендігін мойындауымыз керек.

Афоризмнің бірінші ерекшелігі - ақиқатқа ұмтылған терең ой.

Афоризмнің екінші ерекшелігі - олардың қысқалығы, «тоқсан ауыз сөздің тобықтай түйіні» екендігі.

$\checkmark$ Афоризмнің үшінші ерекшелігі - қосымша түсініктемені қажет етпейтіндей, аяқталған ой екендігі.

Афоризмнің төртінші ерекшелігі - айтылған ойдың анықтығы, дәлдігі.

Афоризмнің бесінші, әрі негізгі ерекшелігі - ойдың көркемдігі, адамзат ақыл ойының асыл қазынасының сыртқы сұлу сымбаты, эстетикалық тартымдылығы.

Афоризмдер туралы анықтамаларға бір мақала аясында шолу жасау мүмкін еместігін ескере отырып, 1998 жылы «Ана тілі» баспасынан шыққан «Әдебиеттану терминдер сөздігінің" [2] 206-бетінде берілген филология ғылымдарының докторы С. Негимов берген анықтаманы келтірейік.

«Қанатты сөз жанрлық белгісі жағынан мақал-мәтелдерге өте ұқсас. Айырмашылығы, мақалмәтелдердің авторы белгісіз, шыққан тегі белгісіз, халық шығармашылығына жатса, қанатты сөз авторы бар не нақты болмаған күнде аңыз күйінде ауызша болса да бүгінгі күнге жеткен 
қанатты сөздің мол болуы сол тілдің сөз байлығын, тіл орамдылығын және ұлттық бейнелік ерекшеліктерін байқатады».

Бұл анықтамадан фольклор мен афоризмдер арсындағы ұқсастық нақты көрсетілген. Әйтсе де «ауызша болса да бүгінгі күнге жеткен» деген пікірдің себебін әдебиетіміздегі бұл жанрдың арнайы қарастырылмағандығына, афоризмдердің өміршең жанр ретінде күннен күнге толығып келе жатқандығының ғылыми түсініктемесі қазақ әдебиетінде әлі жасалмағандығынан деп білуіміз керек. Ауыз әдебиетіндегі мақал- мәтелдердің қысқалығына, ритмділігіне, мағыналығына қарап орыс ғылымының бір топ ғалымдары оларды афоризмдерден мүлдем ара жігін ажыратып қараса, екінші бір ғалымдар тобы, керісінше, мақал-мәтелдерді афоризмдермен бірге қарастыруды ұсынады. Ал әдебиеттің кейбір жанрлық түріне арналған сөздіктерде афоризмдерді тек тақырып аясына қатысты ғана алып, анықтама беруге тырысады. Мысалы А.Квятковскийдің «Поэтикалық сөздігін» [3] алайық.

«Афоризм (греч.) изречение, выражающее с предельной лаконичностью в отточенной форме какую-либо оригинальную мысль. Афористические строки нередки в стихах русских поэтов. Привычка свыше нам дана, Замена счастию она. (А. Пушкин); Поэтом можешь ты не быть, Но гражданином быть обязан. (Н. Некрасов); Мысль изреченная есть ложь. (Ф. Тютчев); Ненавижу всяческую мертвечину, Обожаю всяческую жизнь.

Маяковский); Чем продолжительный молчанье, Тем удивительнее речь.

Ушаков). Афоризмами насыщена комедия А. Грибоедова «Горе от ума», например: «... Счастливые часов не наблюдают; Служить бы рад, прислуживаться тошно; Блажен, кто верует тепло ему на свете.»

Сонау Тоныкөк, Күлтегін ескерткіштері мен көне түркі жазба ескерткіштеріндегі, бертін келе жыраулар поэзиясы мен қазақ әдебиетінің XIX, XX ғасырлардағы мол мұрасында кездесетін қанатты сөздер қазақ әдебиетіндегі бұл жанрдың тамырының тереңдігін, ауқымының кеңдігін көрсетеді. Қазақ халқының қаһарман ұлы, жазушы Бауыржан Момышұлының қанатты сөздері халық арасында кең тарағаны белгілі. Бұл туралы ізденушінің бірнеше мақалалары жарық көрді. Оқырман қауымға Құлмат Өмірәлиевтің «Абайдың афоризмі» (Алматы: Қазақстан баспасы, 1993, 124 б.) [4], Әбділхамит Нарымбетов дайындаған «Ғабит Мүсіреповтің күнделігі» (Алматы. Ана тілі баспасы. 1997, 2886.) [5], Әлия Бөпежанова дайындаған 19781992 жылдар арасындағы Асқар Сүлейменовтің «Шашылып түскен тіркестері» (Сүлейменов А.Шығармаларының толық жинағы.-Алматы:Қазығұрт.-2006) [6] жинақтары кеңінен таныс. Бұл тұрғыда баспасөз бетінде осы жанрда жиі көрінген Қадыр Мырзалиев, Мұзафар Әлімбаев қаламынан туған қанатты сөздерді айту орынды.

Шығармаларының дүниетанымдық, интеллектуалдық қуаты күшті жазушы, драматург, аудармашы А.Сүлейменов қанатты сөздерінің философиялық астары да терең болып келеді. Бір ғана ұлы ақын Абайға қатысты ойларына тоқталу арқылы ғана жазушының сұңғыла ұғым тереңдігін байқауға болатындай.

$\checkmark$ Келер қазақтың да ішетін уы мен балы - Абай.

Қазақтың екі «жауы» бар. Бірі, дос-жауы - Абай. Қалғандары - қас жауы.

Абайдың қазағынан қара үзіп кеткен қазақ жоқтың қасы.

Талант - тұяқ, Абай - жол. Сол жолмен анау Жидебайға, мынау Қарауылға кемеңгер де келеді, кеще де келеді. Мұнда «үйренемін» деп, «үйретемін» деп келмеу керек... Мұнда тазарамын, арыламын деп келу керек. Елдің неге келгенін білмеймін. Мен өзім арыламын деп келдім. 
Кезінде ұлттық «Ана тілі» [7] газеті сөз өнерінің жүйрігі Зейнолла Қабдоловтың біраз қанатты сөздерін келтіре отырып, редакция атынан оқырманнан ел арасына кең тараған басқа да ғалымның қанатты сөздерін білетіндердің хабарласуын сұрағандығы белгілі. Міне бұл үрдіс негізінен кемеліне келген әдебиеттерде қалыптасатын үрдіс. Келесі кезекте Қабдолов айтқан қанатты сөздерге тоқталайық:

$\checkmark$ Әдебиет ардың ісі.

Жазушы талант, тағдыр.

Жазушы ұлттың ұяты, иманы, намысы.

$\checkmark$ Жазушы өз дәуірінің ұлы, өз ғасырының үні.

Махамбеттің әр сөзі құйылған құрыш, қорытылған қорғасын. Оны өңдеп жөндеймін деп жасытпақ керек.

$\checkmark$ Махамбет пен Абайға редакция жүрмейді.

$\checkmark$ Бүгінде Толстойды оқымай орысты, Бальзакты оқымай французды білдім деу қандай қиын болса, Әуезовті оқымай қазақты білдім деу сондай қиын.

$\checkmark$ Жазушының ең жақсы шығармасы жазылмаған яки жазатын шығармасы.

$\checkmark$ Жаза білу, жазғаныңды сыза білу шеберлік. Шеберліктен туатын шедевр осы әрекеттің астында жатыр.

$\checkmark$ Ұлтсыздық имансыздық.

$\checkmark$ Тамыры жоқ ағаш, тарихы жоқ халық болмайды.

Мүсіреповті мадақтаудың керегі жоқ, Мүсіреповпен мақтану керек.

$\checkmark$ Талант деген қыран секілді қанатты нәрсе.

$\checkmark$ Ұстаз болу өз уақытыңды аямау, өзгенің бақытын аялау.

Кезінде баспасөз бетінде қазақ афоризмдерінің толығуына сүбелі үлес қосқан Қадыр Мырзалиевтің жарияланған қанатты сөздеріне [8] алғысөз ретінде афоризмдер туралы ақтарыла айтқан мына бір өзіндік пікірі қанатты сөздің шығу табиғатынан оқушысын хабардар ететіндей: «Афоризм дегеніміз - белгілі бір күні басталып, белгілі бір күні біте қалатын шығарма емес. Ол ғұмыр бойы айтылып, ғұмыр бойы қағазға түсіп, өмірдің соңғы сәтіне шейін созыла беретін дүние. Афоризм қызық жанр. Ол негізінен, ауыз әдебиетіне жатады. Ауызша тарайды. Біреу айтады, біреу қағып әкетеді. Содан кейін қағазға түседі. Өкінішке орай, ауыздан шыққанның бәрі қағазға түсе бермейді. Қағазға түскеннің бәрі бірдей кітапқа кірмейді. Кіргеннің бәрі бірдей тарихта қалмайды. Олар да екшеледі... қанатты сөз болуға лайық, татымды тіркес менің аузымнан бірінші рет қашан шықты. Ол жағы маған беймәлім. Есімде жоқ. Адам өз сөзін өзі бағалай бермейді. Сөзді қадірлеу қасиеті кейін, біраз кейін келді».

Ойының тереңдігімен, құрылымының көркемдігімен ерекшеленетін қанатты сөздер қай әдебиеттің болмасын қаймағы болып табылады, әрі ол жеке жанр ретінде сындарлы зерттеуді қажет етеді. Ал түркі тілдерінің ішінде тереңдігімен де, кемелділігімен де топ бастайтын қазақ әдебиетіндегі құнарлы қанатты сөздер ғылыми саралау мен бағалаудан кейін өз кезегінде орнын тауып, қазақ әдебиеттану ғылымының деңгейін әлемдік биік белестерге көтеруге өз үлесін қосатыны анық.

\section{ПАЙДАЛАНҒАН ӘДЕБИЕТТЕР}

1. Мырзалиев Қ. Алмас жерде қалмас.-Алматы:

2. Әдебиеттану. Терминдер сөздігі. Құрастырушылар 3. Ахметов, Т. Шаңбаев. Алматы:Ана тілі. 1998. -384 б. 
3. Квятковский А. Поэтический словарь. -Москва. Издательство «Советская энциклопедия», 1996. -376 б.

4. Өмірәлиев Құлмат . Абайдың афоризмі. Алматы: Қазақстан баспасы. -1993.- 124 б.

5. Нарымбетов Әбділхамит. Ғабит Мүсіреповтің күнделігі. -Алматы: Ана тілі баспасы. 1997, 2886.)

6. Сүлейменов А. Шашылып түскен тіркестер. - Сүлейменов А. Шығармаларының толық жинағы.-Алматы:Қазығұрт.I-II-III-IV T.-2006

7. «Ана тілі» газеті. №50. желтоқсанның 14-і, 2006 ж., 6-бетте.

8. «Егемен Қазақстан» газеті. 2005 жыл, 6 қаңтар, 4-бетте. 